Pacific Northwest

National Laboratory

Operated by Battelle for the
U.S. Department of Energy

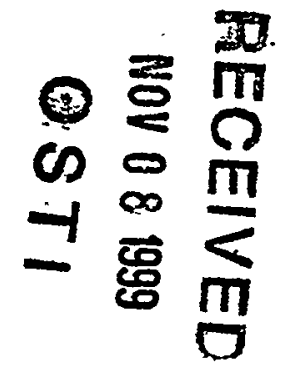

\section{Potential for Waste Stratification from Back-Dilution in Tank 241-SY-101}

Z. I. Antoniak

P. A. Meyer

September 1999

Prepared for the U.S. Department of Energy under Contract DE-AC06-76RLO 1830 


\section{DISCLATMER}

This report was prepared as an account of work sponsored by an agency of the United States Government. Neither the United States Government nor any agency thereof, nor Battelle Memorial Institute, nor any of their employees, makes any warranty, express or implied, or assumes any legal liability or responsibility for the accuracy, completeness, or usefulness of any information, apparatus, product, or process disclosed, or represents that its use would not infringe privately owned rights. Reference herein to any specific commercial product, process, or service by trade name, trademark, manufacturer, or otherwise does not necessarily constitute or imply its endorsement, recommendation, or favoring by the United States Government or any agency thereof, or Battelle Memorial Institute. The views and opinions of authors expressed herein do not necessarily state or reflect those of the United States Government or any agency thereof.

\section{PACIFIC NORTHWEST NATIONAL LABORATORY \\ operated by \\ BATTELLE \\ for the \\ UNITED STATES DEPARTMENT OF ENERGY \\ under Contract DE-ACO6-76RLO 1830}

Printed in the United States of America

Available to DOE and DOE contractors from the

Office of Scientific and Technical Information, P.O. Box 62, Oak Ridge, TN 37831; prices available from (615) 576-8401.

Available to the public from the National Technical Information Service, U.S. Department of Commerce, 5285 Port Royal Rd., Springfield, VA 22161

PNNL-XXXXX

This document was printed on recycled paper.

$(9 / 97)$ 


\section{DISCLAIMER}

Portions of this document may be illegible in electronic image products. Images are produced from the best available original document. 


\title{
Potential for Waste Stratification from Back-Dilution in Tank 241-SY-101
}

\author{
Z I Antoniak
}

PA Meyer

September 1999

Prepared for

the U.S. Department of Energy

under Contract DE-AC06-76RLO 1830

Pacific Northwest National Laboratory

Richland, Washington 



\section{Summary}

Since late 1997, the floating crust layer in Hanford Tank 241-SY-101 (SY-101) has grown about two meters by gas accumulation. To reverse crust growth and reduce its retained gas volume, the waste in SY-101 will be diluted by transferring at least 300,000 gal of waste out of the tank and replacing it with water. In the fall of 1999, approximately 100,000 gal of this waste will be transferred into Tank SY-102; within a few days of that initial transfer, approximately $100,000 \mathrm{gal}$ of water will be added to SY-101.

This initial back-dilution is being planned to ensure that the base of the floating crust layer will be lifted away from the mixer pump inlet with minimal effect on the crust itself. The concern is that the added water will pool under the crust, so the resulting fluid mixture will be too light to lift the crust away from the mixer pump and dissolution at the crust base could cause unwanted gas release. To ensure sufficient mixing to prevent such stratification, water will be added near the tank bottom either through an existing sparge ring on the base of the mixer pump or through the dilution line at the inlet of the transfer pump.

A number of simulations using the TEMPEST code showed that the mixing of the water and waste by this method is rapid, and the water does not pool under the crust. Although a density gradient is present, its magnitude is small compared with the difference between the slurry and water density. The result is essentially the same whether water is introduced at the base of the mixer pump or at the transfer pump. There is little effect of water flowrate up to the $500 \mathrm{gpm}$ studied. In all cases, the minimum density remained above that required to float the crust and well above the density of saturated liquid. This indicates that the base of the crust will rise during back-dilution and there will be little or no dissolution of the crust base because the water will be close to saturation from the dissolution of solids in the mixed slurry. 



\section{Contents}

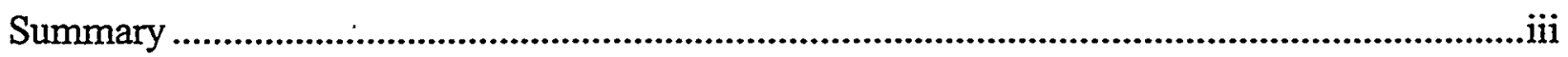

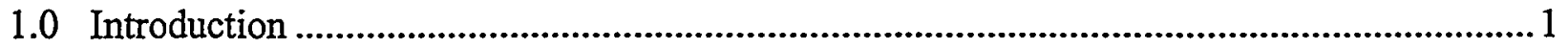

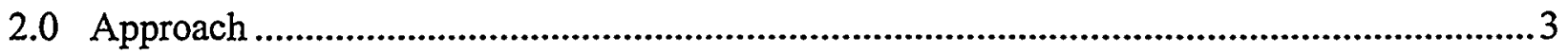

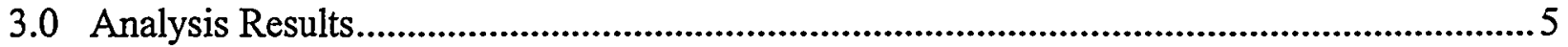

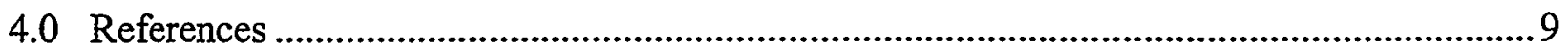

\section{Figures}

$1 \quad 100$ gpm Inflow at 24 in. Elevation of Mixer Pump Sparge Ring into $3 \mathrm{cP}$ Slurry

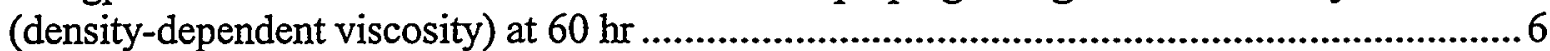

$2100 \mathrm{gpm}$ Inflow at $96 \mathrm{in}$. Elevation of Transfer Pump Inlet into $100 \mathrm{cP}$ Slurry

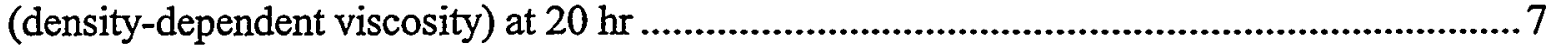

3 Minimum Mixture Specific Gravity as a Function of Time.................................................

\section{Tables}

1 Calculated Mixture Specific Gravity Shortly after Cessation of Water Inflow ......................5

2 Comparison of Calculated Water Mass Fraction under Crust at Start of Back-Dilution......... 8 


\subsection{Introduction}

Since late 1997, the floating crust layer in Hanford Tank 241-SY-101 (SY-101) has grown about two meters by gas accumulation (Stewart et al. 1998; Conner and Koreski 1999). To reverse crust growth and reduce its retained gas volume, the waste in SY-101 is planned to be diluted by transferring at least 300,000 gal of waste out of the tank and replacing it with water (Raymond 1999). A submersible transfer pump has been installed that is designed to introduce water at the inlet to provide in-line dilution to make the waste pumpable and reduce the likelihood of transfer line plugging. At the same, time the mixer pump must continue operating to prevent a return to buoyant displacement gas release events.

The initial transfer of approximately 100,000 gal of waste from SY-101 into SY-102 is planned for the fall of 1999, followed within a few days by addition of approximately 100,000 gal of water to SY-101. This back-dilution is being planned to ensure that the base of the floating crust layer will be lifted away from the mixer pump inlet with minimal effect on the crust itself. The concern is that the natural tendency for the much lighter dilution water to rise and pool beneath the crust would make the resulting fluid mixture too light to float the crust. If this happens, adding water will not lift the crust away from the mixer pump, and dissolution at the crust base could cause unwanted gas release. However, as long as the volume of added water is not too large and the plume of dilution water mixes sufficiently, significant stratification should not occur in the waste.

To ensure mixing, water heated to the bulk tank temperature will be added at 30-70 gpm near the tank bottom either through an existing sparge ring on the base of the mixer pump or through the dilution line at the inlet of the transfer pump. Subsequent back-dilutions are envisioned to involve water additions on top of or directly under the crust; however, technical issues associated with gas release, crust dissolution mechanics, and crust floatation have yet to be fully resolved.

The purposes of this study were 1) to confirm that back-dilution through the mixer pump sparging ring or transfer pump dilution line provides sufficient mixing and 2) to determine whether mixing depends on dilution flowrate. Section 2 describes the approach used to analyze mixing, including both the TEMPEST hydrothermal code (Trent and Eyler 1993) and an empirical model for plume mixing. Section 3 presents the results of the analyses, and cited references are listed in Section 4. 


\subsection{Approach}

The approach used to assess the potential for stratification was a computational fluid dynamic computer simulation of back-dilution in the tank from the two locations. A twodimensional TEMPEST model was created specifically for back-dilution from the mixer pump sparging ring. A 2-D model is appropriate for this case because the mixer pump is near the tank center and the resulting flows are nearly axisymmetric. The model consists of 47 radial and 28 vertical divisions with variable spacing, for a total of 1316 computational cells.

A second, three-dimensional model was also created to address back-dilution at the transfer pump inlet. Because the transfer pump is located in riser 007 (5B) at a 20-ft radius, a twodimensional model would not accurately represent the back-dilution flow and mixing behavior. This three-dimensional model contained 40 radial, 28 vertical, and 21 azimuthal divisions for a total of 23,520 computational cells. Small cells are used in the water inflow region where velocity and density gradients are large.

The models represent the assumed waste configuration after removal of 100,000 gallons of slurry. The waste is represented as a single layer of convective slurry with variable density and viscosity. The 50-60-in. loosely settled layer is considered part of the slurry. The viscosity submodel computes the slurry viscosity as a function of the local water volume fraction. The models simulate slurry convection only, both forced and that due to buoyancy. However, because the model is isothermal at a uniform $49^{\circ} \mathrm{C}\left(120^{\circ} \mathrm{F}\right)$, thermal natural convection mixing is conservatively neglected. Effects of dissolution of slurry solids are not modeled. This is conservative because dissolution of solids during water/waste mixing will tend to reduce density gradients and result in less potential for stratification. For added conservatism, the simulations were performed with molecular and turbulent diffusion models turned off.

TEMPEST cannot simulate a moving boundary so the base of the crust is assumed to be at a constant 312-in. level. Therefore, to satisfy continuity, the model requires an artificial outflow cell to balance the water inflow. This cell is located at the tank bottom, at the outer wall/radius to minimize its effect on the plume. Because the 100,000-gal back-dilution is less than $10 \%$ of the total waste volume, the effects of assuming a stationary crust are considered negligible.

Back-dilution water was assumed to flow into the tank at 30,100,200, or 500 gpm either through the bottom sparge ring (at 24-in. elevation) or at the transfer pump inlet (at about 96-in. elevation). At the various flow rates, the time needed for 100,000 gal of water replacement varies from 3 to 56 hours. One additional case simulated a total back-dilution volume of 200,000 gal at a 100-gpm flowrate. 


\subsection{Analysis Results}

The purpose of the simulations was to study the degree of buoyant mixing of dilution water with the mixed slurry for a 100,000-gal water addition after a 100,000-gal waste removal. By parametrically varying slurry viscosity and water flow rates, the range of conditions that could occur during this operation were simulated for the two proposed locations for water addition. All simulations were run as transients, most of them to a "real" time of 100 hours. Typically about two days of CPU run time on the PNNL SGI computer were required to complete a 2-D run. The 3-D model required approximately a week to complete a run.

The results of all the simulations run are summarized in Table 1. Details are shown in Figures 1 and 2, which plot typical density contours shortly after water inflow has ceased. Essentially no further mixing occurred after cessation of inflow. Mixing is quite good, even with a 200, 000-gallon transfer/back-dilution or a 500-gpm back-dilution flow at the transfer pump. This is clearly evident in Figure 3. The minimum specific gravity seen by the crust is 1.46 for a

Table 1. Calculated Mixture Specific Gravity Shortly after Cessation of Water Inflow

\begin{tabular}{|c|c|c|c|c|c|c|}
\hline $\begin{array}{l}\text { Slurry }^{(a)} \\
\text { viscosity } \\
\text { (cP) }\end{array}$ & $\begin{array}{l}\text { Flow } \\
\text { (gpm) }\end{array}$ & $\begin{array}{l}\text { Inflow } \\
\text { elevation } \\
\text { (in.) }\end{array}$ & $\begin{array}{l}\text { Duration for } \\
100,000 \text { gal } \\
(\mathrm{hr})\end{array}$ & $\begin{array}{l}\text { Max. mixture } \\
\text { specific } \\
\text { gravity }\end{array}$ & $\begin{array}{l}\text { Min. mixture } \\
\text { specific } \\
\text { gravity }\end{array}$ & $\begin{array}{l}\text { Time specific } \\
\text { gravity } \\
\text { calculated }\end{array}$ \\
\hline 3 & 100 & 24 & 16.67 & 1.54 & 1.53 & 20 \\
\hline 3 & 30 & 24 & 55.56 & 1.55 & 1.55 & $45^{(b)}$ \\
\hline 3 & 100 & 24 & 16.67 & 1.53 & 1.52 & $\begin{array}{c}20 \\
\text { (see Figure 1) }\end{array}$ \\
\hline 3 & 30 & 24 & 55.56 & 1.53 & 1.53 & 60 \\
\hline 30 & 100 & 24 & 16.67 & 1.53 & 1.52 & 20 \\
\hline 30 & 30 & 24 & 55.56 & 1.53 & 1.53 & 60 \\
\hline 100 & 100 & 24 & 16.67 & 1.53 & 1.52 & 20 \\
\hline 100 & 30 & 24 & 55.56 & 1.56 & 1.52 & $35^{(b)}$ \\
\hline 1000 & 100 & 24 & 16.67 & 1.53 & 1.52 & 20 \\
\hline 1000 & 30 & 24 & 55.56 & 1.53 & 1.53 & 60 \\
\hline 100 & 200 & 24 & 8.33 & 1.54 & 1.52 & 10 \\
\hline 100 & 500 & 24 & 3.33 & 1.54 & 1.52 & 4 \\
\hline 100 & 100 & 24 & $\begin{array}{c}33.3 \\
(200,000 \mathrm{gal}) \\
\end{array}$ & 1.47 & 1.46 & $\begin{array}{c}35 \\
\text { (see Figure 3) } \\
\end{array}$ \\
\hline \multicolumn{7}{|c|}{ The results below represent water inflow at the 20-ft radius simulated with a 3-D model. } \\
\hline 100 & 500 & 96 & 3.33 & 1.58 & 1.50 & 4 \\
\hline 100 & 100 & 96 & 16.67 & 1.56 & 1.52 & $\begin{array}{c}20 \\
\text { (see Figures 2, 3) } \\
\end{array}$ \\
\hline 100 & 30 & 96 & 55.56 & 1.55 & 1.52 & 60 \\
\hline \multicolumn{7}{|c|}{$\begin{array}{l}\text { (a) At the beginning of the simulations. Viscosity decreased as mixture volume fraction of water } \\
\text { increased except for the first two runs, when volume fraction was kept constant. } \\
\text { (b) Incomplete run. }\end{array}$} \\
\hline
\end{tabular}




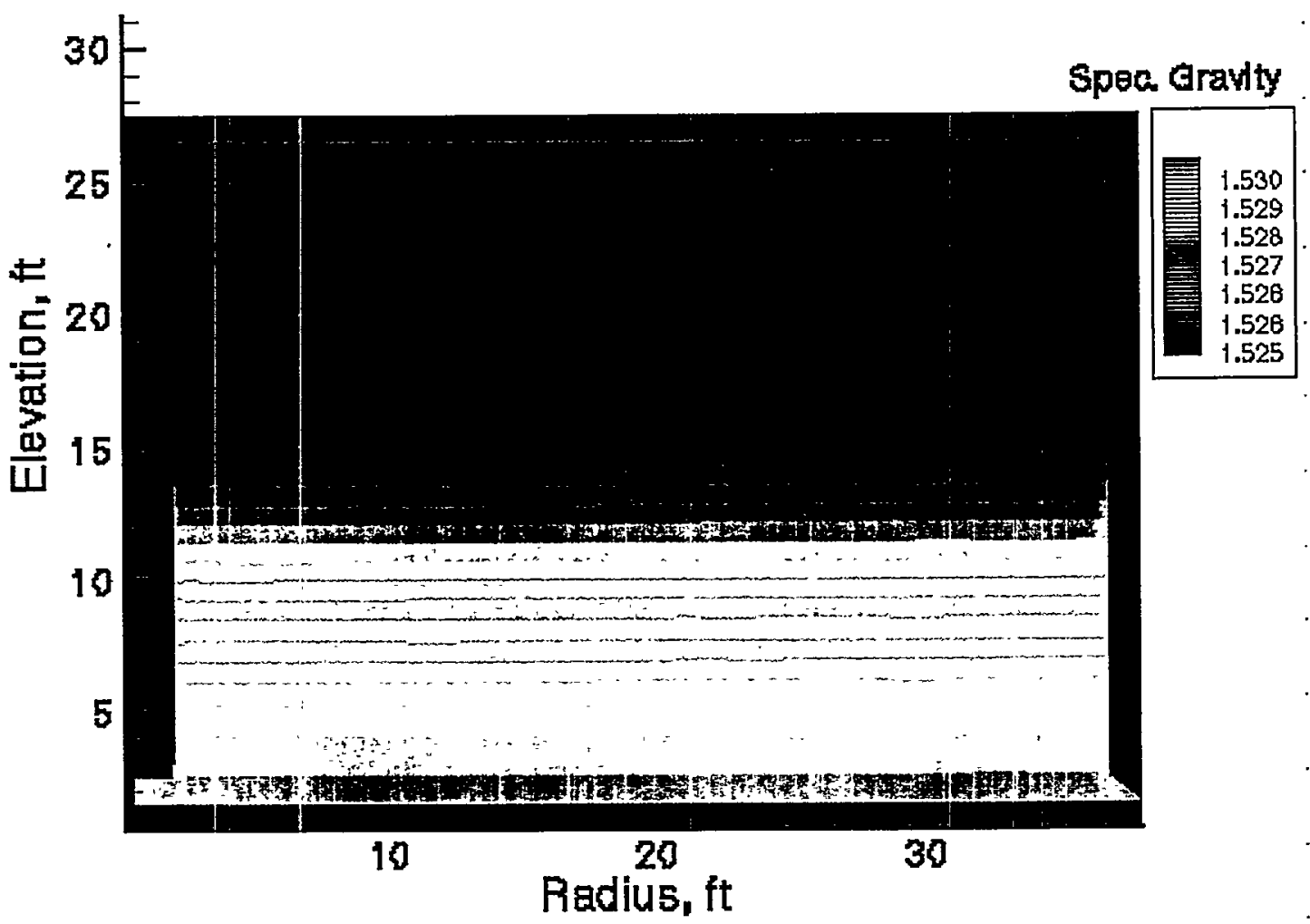

Figure 1. $100 \mathrm{gpm}$ Inflow at 24 in. Elevation of Mixer Pump Sparge Ring into $3 \mathrm{cP}$ Shurry (density-dependent viscosity) at $60 \mathrm{hr}$

200,000 -gal back-dilution case. The specific gravity necessary to float the crust is calculated to be 1.41-1.43 (Stewart et al. 1999). However, as Figure 3 indicates, this is unlikely to happen even with a 200,000-gal transfer/back-dilution or with back-dilution at the transfer pump.

The simulation results presented above show that mixing of the water and waste is rapid, and the water does not pool under the crust. Mixing is somewhat less complete with water injection at the transfer pump, which is about six feet higher than the base of the mixer pump. The rates of water inflow had only a minor influence on mixing, if one accounts for the different inflow duration. That is, 100 hours after the beginning of back-dilution there is little to distinguish among all the cases with the same water injection location. The initial waste viscosity also plays a very minor role in the mixing process, and its influence can be ignored.

An alternative method, using hand calculations with the equations as described by Epstein and Burelbach (1998), was used to estimate mixing of the back-dilution water "plume." These equations only approximate the mixing process by assuming a circular plume released into an infinite (radially) medium and do not include real geometry, fluid viscosity, or water accumulation effects. Nevertheless, as a bounding check, these calculations also indicate that mixing is rapid, and the specific gravity of the mixture beneath the crust approaches the specific gravity of the undiluted slurry at 1.60 (see Table 2). These specific gravities compare favorably with TEMPEST results, calculated approximately $60 \mathrm{~s}$ after back-flow initiation when the flow field had established itself (this is also evident from backward extrapolation of results from Figure 3), but the total back-dilution volume was still low. 


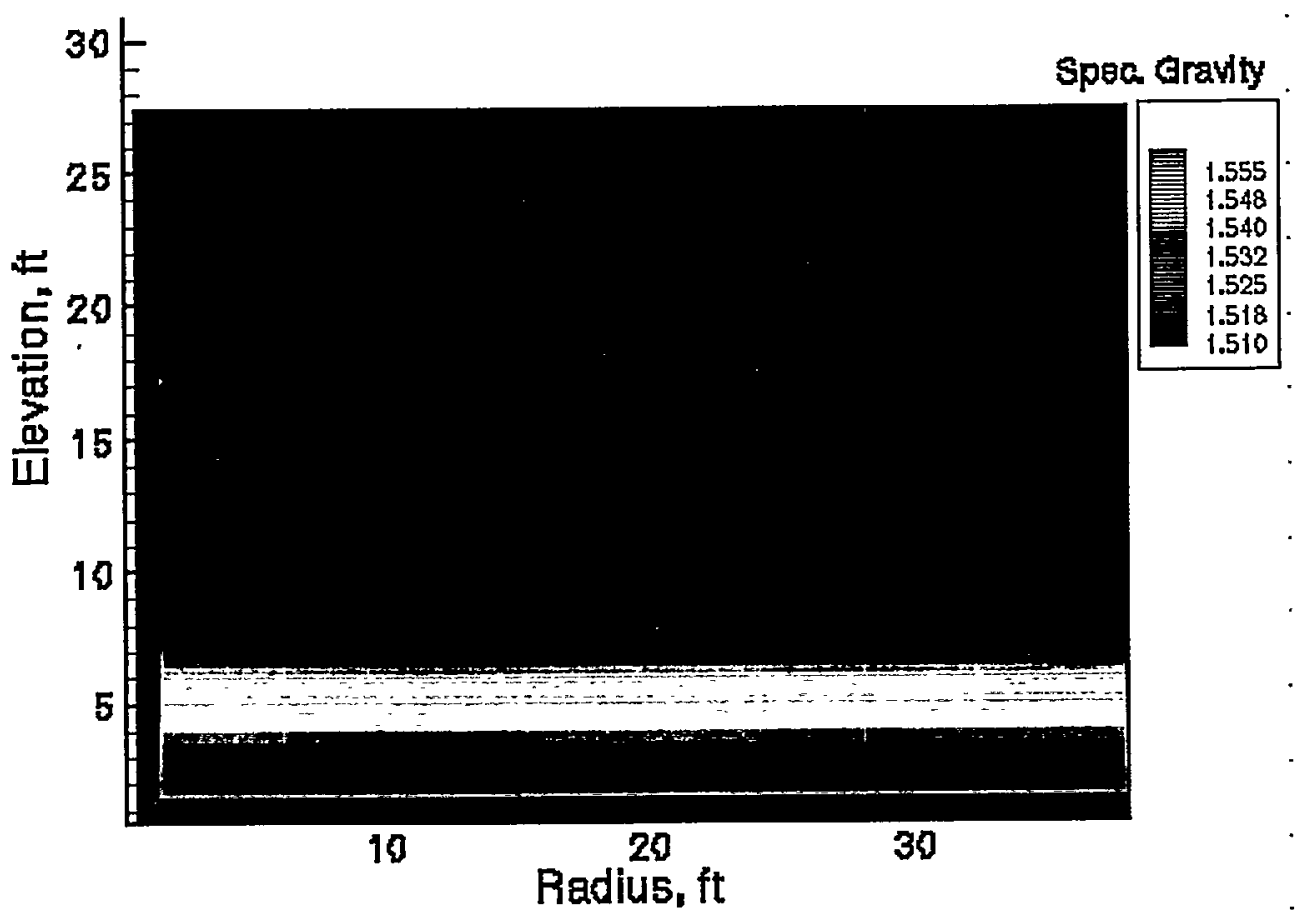

Figure 2. $100 \mathrm{gpm}$ Inflow at $96 \mathrm{in.} \mathrm{Elevation} \mathrm{of} \mathrm{Transfer} \mathrm{Pump} \mathrm{Inlet} \mathrm{into} 100 \mathrm{cP}$ Slurry (density-dependent viscosity) at $20 \mathrm{hr}$

\section{Minimum Mixture Specific Gravity}

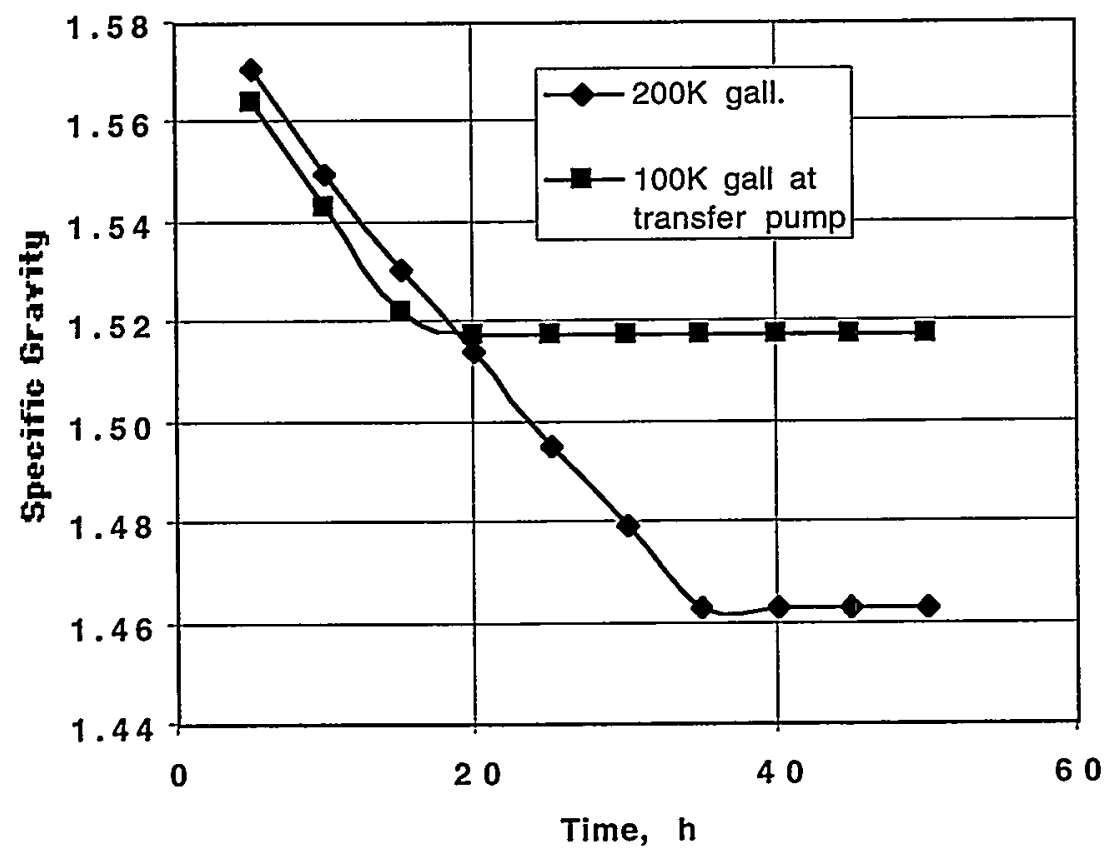

Figure 3. Minimum Mixture Specific Gravity as a Function of Time 
Table 2. Comparison of Calculated Mixture Specific Gravity under the Crust at Start of Back-Dilution

\begin{tabular}{|c|c|c|c|c|}
\hline \multirow{2}{*}{$\begin{array}{c}\text { Slurry } \\
\text { viscosity } \\
(\mathrm{cP})\end{array}$} & \multirow{2}{*}{$\begin{array}{c}\text { Flow } \\
(\mathrm{gpm})\end{array}$} & $\begin{array}{c}\text { Inflow } \\
\text { elevation } \\
\text { (in.) }\end{array}$ & $\begin{array}{c}\text { Method of Epstein and } \\
\text { Burelbach (1998) }\end{array}$ & $\begin{array}{c}\text { TEMPEST } \leq 60 \text { seconds } \\
\text { after starting back- } \\
\text { dilution flow }\end{array}$ \\
\hline 100 & 30 & 24 & 1.598 & 1.596 \\
\hline 100 & 500 & 24 & 1.593 & 1.596 \\
\hline 100 & 30 & 96 & 1.597 & 1.596 \\
\hline
\end{tabular}




\subsection{References}

Conner JM and GM Koreski. 1999. Quarterly Review of 241-SY-102 Mixer Pump Data: January-March 1999. HNF-4511, Lockheed Martin Hanford Corp., Richland, Washington.

Epstein M and JP Burelbach. 1998. Experimental and Theoretical Turbulent Diffusion Modeling of Light Gas Releases in a Tank Headspace: 2. Local Releases. FAI/98-50, Fauske \& Associates, Burr Ridge, Illinois.

Raymond RE. 1999. Tank 241-SY-101 Surface Level Rise Remediation Project Plan. HNF-3824, Lockheed Martin Hanford Corp., Richland, Washington.

Stewart CW, JM Alzheimer, G Chen, and PA Meyer. 1998. In Situ Void Fraction and Gas Volume in Hanford Tank 241-SY-101 as Measured with the Void Fraction Instrument. PNNL12033, Pacific Northwest National Laboratory, Richland, Washington.

Stewart CW, SD Rassat, and JH Sukamto. 1999. Effects of Back-Dilution on Buoyancy of the SY-101 Crust Layer. PNNL-13040, Pacific Northwest National Laboratory, Richland, Washington. 
PNNL-13138

UC-2030

\section{Distribution}

No. of

Copies

Offsite

2 Office of Scientific and Technical Information

\section{Onsite}

14 PHMC Team

W. B. Barton

R. E. Bauer (3)

J. R. Biggs

R. J. Cash

J. M. Grigsby (3)

B. K. Hampton

G. D. Johnson

N. W. Kirch

L. J. Kripps

R. E. Raymond
R2-11

S7-73

S7-07

S7-73

R1-44

G1-24

S7-73

R2-11

S7-73

S7-70
No. of

Copies

3 DOE Richland Operations Office

C. A. Groendyke (3)

H6-60

21 Pacific Northwest National Laboratory

Z. I. Antoniak

K7-15

S. Q. Bennett

$\mathrm{K} 7-90$

J. W. Brothers (4)

K9-20

P.A. Gauglitz

K6-28

W. L. Kuhn

K7-15

P. A. Meyer

$\mathrm{K} 7-15$

Y. Onishi

K7-15

S. D. Rassat

K6-28

K. P. Recknagle

K7-15

C. W. Stewart (3)

K7-15

B. E. Wells

K7-15

Information Release (5)

K1-06

Distr. 1 